\title{
MEASURING TO IMPROVE VS. MEASURING TO PROVE: UNDERSTANDING THE ADOPTION OF SOCIAL PERFORMANCE MEASUREMENT PRACTICES IN NASCENT SOCIAL ENTERPRISES
}

\author{
Saurabh Lall \\ Assistant Professor \\ School of Planning, Public Policy and Management \\ University of Oregon \\ slall@uoregon.edu \\ https://doi.org/10.1007/s11266-017-9898-1
}

\begin{abstract}
Social enterprises are described as organizations with dual objectives - social and commercial.

While the measurement of commercial performance is relatively straightforward and well understood, our understanding of the factors related to measuring social performance are more ambiguous. Is the adoption of social performance measurement (SPM) practices more related to external pressures, such as the need to demonstrate legitimacy to funders and peers, or is it more closely related to the growing rationalization within the social sector? We examine the relationship between external and internal factors and the adoption of SPM using a novel dataset of 1864 nascent social enterprises from around the world. Our findings suggest support for the argument that the adoption of SPM in social enterprise is related to the growing rationalization of the social sector, which challenges some of the past research on this topic, and provides a more nuanced perspective of SPM in social enterprise.
\end{abstract}

\section{KEYWORDS}

Social enterprise, social performance measurement, rationalization, legitimacy, impact measurement 


\section{INTRODUCTION}

As the study of social enterprises continues to grow, there is increasing attention by academics and practitioners to the methods and practices employed by these organizations to measure their social performance (notably Arena et al., 2015; Nicholls, 2009; Bull, 2007; Somers, 2007). As organizations with both social and financial objectives, social enterprises face an imperative to manage their performance in both domains, and to also establish their legitimacy in financial and social terms to multiple stakeholders (Arena et al., 2015; Ebrahim et al.; 2014). In recent years, there has been considerable attention by both practitioners (Schiff et al., 2016; Edens \& Lall, 2014; Hehenberger et al., 2013) and academics (Arena et al., 2015; Bagnoli \& Megali, 2011; Bull, 2007) to the social performance measurement practices employed by social enterprises. There are a wide range of social performance measurement tools, initiatives, and frameworks that have been developed by both practitioners and academics, as subsequently discussed in the literature review section. For the purpose of this study, we use the term social performance measurement (SPM) in the manner employed by Ebrahim \& Rangan (2014), to encompass the broad range of practices (such as impact evaluation, outcome measurement, and program monitoring) adopted by an organization to measure its progress towards its social goals.

Social enterprises, offer a distinct challenge in the context of SPM, due to the dual nature of their objectives, and the need to balance both social and financial performance. While the need to measure financial performance is relatively straightforward, and the methods standardized, the antecedents and approaches of measuring social performance are less clear (Ebrahim, et al., 2014; Ebrahim \& Rangan, 2014; Bagnoli \& Megali, 2011; Ormiston \& Seymour, 2011). In particular, we observe two types of motivating factors. First, social enterprises are responsible to multiple stakeholders, often with diverging interests (such as beneficiaries, funders, and peers), 
and may face competing externally driven-demands for accountability and legitimacy (Arena et al., 2015; Bagnoli \& Megali, 2011; Nicholls, 2009). Second, the steady trend of rationalization and marketization of the social sector over the past four decades has set expectations and norms of rationalized practices such as SPM, reflecting internal influences (Ebrahim et al., 2014; Dey \& Steyaert, 2010; Hwang \& Powell, 2009; Eikenberry \& Kluver, 2004). In this study, we examine the external and internal factors associated with the adoption of SPM practices in social enterprise. We build on a small, but growing body of rich, qualitative literature on this topic (notably Arena et al., 2015; Scarlata et al., 2012; Bull, 2007; Ormiston \& Seymour; 2011; Nicholls, 2009), as well as related literature from the nonprofit field to inform the development of six hypotheses. We then use a novel dataset of 1864 early-stage social enterprises from around the world to empirically examine these relationships, and contribute to a stronger understanding of social performance measurement in the field of social enterprise.

This study is structured as follows: First, we examine the literature on social enterprise and social performance measurement, as well as an overview of the external and internal factors that drive the adoption of these practices, leading us to develop six hypotheses. Second, we describe the new dataset used in this study, and our methodological approach to test these hypotheses. We then discuss our results and their implications for research and practice; and finally, conclude with a discussion of limitations, as well as directions for future research.

Our study makes the following contributions to research and practice. First, we develop a theoretical model for examining SPM in the field of social enterprise, that builds on the extant conceptual and empirical literature in the fields of social enterprise and nonprofits. Second, we strengthen the knowledge base in the field by conducting the first large-sample, quantitative analysis of the relationship between internal and external factors, and the adoption of SPM in 
social enterprise. Our findings provide a more nuanced perspective on SPM adoption in social enterprise, by highlighting the role of internal factors such as the background of the founding team, as well as previously unexplored factors such as the influence of cohort-based training programs. Finally, we provide some interesting comparisons to the larger body of literature on this topic in the nonprofit sector, and suggest some implications for scholars and practitioners in the social enterprise and nonprofit sectors. In particular, we suggest that the role of accelerator programs in helping build capacity and providing training to nascent social enterprises deserves further study.

\section{LITERATURE REVIEW}

\section{Background and Core Concepts}

We start by acknowledging that a universal definition of the term "social enterprise" remains elusive, with definitions ranging from nonprofits that employ business practices to large firms practicing corporate social responsibility (Dees, 1998; Dart, 2004; Mair \& Marti, 2006; Dacin, Dacin \& Matear, 2010). However, there appears to be growing consensus among scholars and practitioners that the majority of social enterprises typically display at least two common characteristics - (i) the presence of a social mission; and (ii) a revenue model or ability to earn income (Lepoutre et al., 2013; Terjesen et al., 2011; Dacin, Dacin, and Matear, 2010; Kerlin, 2010; Mair and Marti, 2006). We adopt this narrow definition of social enterprise for the purpose of this study, while acknowledging the broader range of social enterprise characteristics such as innovation, workforce integration, entrepreneurialism, cooperative structures, and democratic governance that are proposed by various schools of thought and policy guidelines (Young \& Lecy, 2012; Defourny, 2010; Teasdale, 2012; Defourny \& Nyssens, 2008; Kerlin, 2006). In adopting this definition, we also acknowledge the wider range of work in defining social 
enterprise, and related terms such as social entrepreneurship and social innovation in academia (Dey \& Steyaert, 2010; Nicholls \& Cho, 2006; Nicholls, 2010; Young \& Lecy, 2012), as well as public policy (Teasdale, 2012). Our study does not aim to contribute to the broader definitional literature on social enterprise, but rather, make an empirical contribution that is focused on the broadly accepted dual nature (social and commercial) of social enterprise.

We also recognize that while tracking financial performance is relatively straightforward, measuring progress towards the achievement of a social objective is considerably more complex, and there is less agreement on the most appropriate and effective ways to measure social performance as noted in past research (Ebrahim and Rangan, 2014; Ebrahim \& Rangan, 2010; Bull, 2007; Paton, 2003). Over the past few decades, there has been tremendous progress in management and social science research in developing new tools and frameworks to measure various aspects of performance in social sector organizations. While much of the development has been the work of consultants, foundations, industry groups, and think-tanks (Nicholls, 2010), there has also been increasing attention to the issue, and more critical analysis by academics. Some of these approaches include, for example, the Balanced Scorecard (Kaplan \& Norton, 1996) which was initially developed to help the corporate sector align non-financial performance measures with its bottom line, and has been adapted for the nonprofit (Kaplan, 2001) and the social enterprise sectors (Somers, 2005; Bull, 2007). Similarly, the Social Return on Investment (SROI) toolkit, initially developed by the Roberts Enterprise Development Fund (now REDF), has been examined from the social enterprise and nonprofit perspectives in a number of academic studies (notably Ridley-Duff \& Bull, 2015; Maier et al., 2015; Arvidson et al., 2013; Flockhart, 2005). The Global Impact Investing Network (GIIN) developed a taxonomy of performance measures known as the Impact Reporting and Investment Standards for the social 
impact investing community, which is widely used for reporting to funders, particularly in North America, but increasingly in other regions as well (Schiff et al., 2016; Barman, 2015). Finally, the social business rating agency, B Lab introduced first the Global Impact Investment Ratings System (GIIRS), which later evolved into the B Impact Assessment (Barman, 2015).

Scholarly examinations of these tools and frameworks have tended to highlight two distinct types of factors associated with their adoption in the social sector. As described previously, past research identifies a symbolic role of performance measurement practices, in an effort to demonstrate legitimacy and accountability to external stakeholders (Barman, 2015; Ormiston \& Seymour, 2011; Nicholls, 2009), and also a more rationalized perspective, as a reflection of the growing professionalization of founders and managers in the social sector (Ebrahim et al., 2014; Eikenberry \& Kluver, 2004; Thomson, 2011; Hwang \& Powell, 2009). We distinguish these two sets of factors as "measuring to prove" (i.e., the externally driven need to demonstrate legitimacy in the social domain to key stakeholders); and "measuring to improve" (i.e., the internally driven norms of marketization and rationalization in the social sector that have emerged over the past four decades), and examine the literature related to both sets of factors. Since the literature on this topic in the field of social enterprise is relatively nascent, we also draw upon the more extensive body of literature in the nonprofit sector to help develop our theoretical framework and hypotheses.

\section{Measuring to Prove (Establishing Legitimacy to Funders)}

Social enterprises are often described to have a dual identity, rooted in two separate institutional logics. ${ }^{\mathrm{a}}$ A social logic that guides their mission-related activities, and a financial logic that requires them to earn sufficient revenues and profits to support their operations (Battilana \& Dorado, 2010). As Galaskiewiecz \& Barringer (2012) argue, this dual identity makes social 
enterprises difficult to categorize, and therefore to hold accountable. Social enterprises embody both social and commercial logics, and are held accountable to measures for nonprofits as well as for-profit businesses, while also facing mistrust from both sides. As Ebrahim et al., (2014) argue, at their core, these organizations combine activities traditionally based in the nonprofit and business sectors, and are therefore bound to face trade-offs between these two missions, and stakeholders on either side. Thus, they face an imperative to demonstrate both social and commercial performance in order to be considered legitimate to external audiences in both domains (Young, 2012; Ebrahim et al., 2014; Dart, 2004).

Nicholls (2009) suggests that while performance measurement may theoretically be used by social enterprises to "enhance their performance" (p. 764), in practice it often takes on a more symbolic role. He notes that many of these approaches have been developed from the perspective of social impact investors and the funders of social enterprises, rather than the enterprises themselves (Nicholls, 2009; Barman, 2015). Nicholls (2009) describes this development as a "top down" movement in establishing social reporting practices, based on the assumption that they "enhance stakeholder accountability, improve transparency, and therefore offer better performance legitimacy" (p. 757). He recognizes the limitations of these approaches, and discusses the corresponding "bottom up" approach that facilitates "greater stakeholder engagement in designing the reporting practices that affect them" (p. 757).

Miller et al., (2010) note that historically, social enterprises have been slow to adopt robust and strong metrics, and measures of social performance have typically been less standardized. They argue that social enterprises that develop strong performance measurement methodologies are more likely to establish legitimacy and raise capital from socially-oriented investors and donors (Miller et al., 2010). 
Arena, et al. (2015) concur with this perspective, and examine this question from an accounting framework perspective. They identify the different categories of external stakeholders that social enterprises typically report to, ranging from foundations and charities, to policymakers, and forprofit investment funds. These external stakeholders may have different, and sometimes competing objectives, and different levels of power and influence, leading to a fragmented approach in SPM, that may not align with the needs of internal stakeholders.

This fragmentation is evident in Ormiston \& Seymour's (2011) study of the "mission measurement paradox" (p. 137). In their qualitative analysis, they find that none of the three social enterprises in their study effectively align their missions with social performance measurement, focusing more on measures related to the growth of the venture (number of beneficiaries reached), rather than the fulfillment of their mission. The social entrepreneurs in Ormiston \& Seymour's study cite a lack of resources, competing informational demands from donors, and the challenge of operationalizing their missions into quantitative measures as barriers to effective measurement. The authors note the limitations of their case-study based approach, and call for empirical research on the antecedents of this misalignment between mission and methods in social enterprise. Our research contributes to this body of literature by addressing the call by Ormiston \& Seymour (2011), and building on the work of these scholars. Interestingly, we see strong evidence of these externally oriented mechanisms in the relationships between nonprofits and their funders. For example, Carman (2011) examines the factors moving nonprofits in the social service, disability, and housing sectors to measure their social performance, and finds the majority of nonprofits are motivated by external factors, explained by resource dependence (Pfeffer \& Salancik, 1978) and institutional isomorphism (DiMaggio \& Powell, 1983). She suggests that many organizations regard these practices as a 
requirement for funders or the need to be considered legitimate, and largely decoupled from their own operations.

Ebrahim $(2002 ; 2005)$ observes that nonprofits are not necessarily opposed to the adoption of social performance measurement, but it is the volume and the suitability of the performance data that creates problems, and nonprofits end up decoupling the information they collect for reporting from operational management and governance decisions. This finding is also supported by Newcomer, et al., (2013) in their study of nonprofit performance measurement in Egypt and Colombia. Finally, Benjamin (2010) draws from new institutional theory, and examines how organizations respond to external pressures to maintain legitimacy. She examines the relationship between funders and grantees, and observes the tension between historic practices followed by the grantees, and the need to adopt new practices required for social performance measurement (Benjamin, 2010).

The mechanisms through which these external pressures influence organizations to adopt SPM practices are largely explained through the organizational theories of institutional isomorphism (DiMaggio \& Powell, 1983), and resource dependency (Pfeffer \& Salancik, 1978). DiMaggio \& Powell (1983) note that organizations may feel both formal and informal pressures (described as coercive pressures) exerted by other organizations upon which they are dependent, to adopt certain practices. Additionally, organizations are motivated by the desire to attract resources, and may be influenced by the need to adopt SPM practices in order to pursue funding from particular types of funders (Powell \& Friedkin, 1986; Useem, 1987). In the nonprofit sector, a number of studies (notably Claeye \& Jackson, 2012; Marshall and Suarez, 2014; and Mitchell, 2014) find that donor agencies and philanthropic funders are a strong influence on the adoption and implementation of SPM practices. 
We find similar evidence in larger surveys of nonprofits and charities. For example, in their survey of 550 nonprofits in the United Kingdom, Ogain et al., (2012), find that while the majority of nonprofits in the United Kingdom (75\%) measured their social performance in some form, over 50 percent of respondents stated that their primary reason for doing so was to report externally to funders, compared to only 22 percent for whom the primary motivation was reporting internally to their boards. Interestingly, only 5 percent mentioned improving services as the primary motivating factor.

However, it is important to note that social enterprises may receive funding from a range of financial sources, with different priorities and expectations in terms of financial and social returns (Hehenberger, 2013; Moore et al., 2011; Milligan and Schöning, 2011; Nicholls \& Pharaoh, 2008). In describing the spectrum of social finance providers, Nicholls \& Pharaoh (2008) explain how purely commercial finance providers may only be interested in financial performance, while at the other extreme, purely charitable funders may expect no financial returns, and therefore only care about social performance. In this context, both scholarly and practitioner research has conceptually explored the relationship between social enterprise and philanthropic funding, and its influential role with nascent social enterprises (Dees, 2008; Koh et al., 2012; Scarlata et al., 2012; Scarlata \& Alemany, 2010). Philanthropic funders are most likely to support social enterprises to maximize their potential for social impact (Dees, 2008), and therefore expect them to measure and report on their social performance (Scarlata \& Alemany, 2010; Spiess-Knafl \& Ashcari-Lincoln, 2015; Nicholls \& Pharoah, 2008).

In addition to funders, several studies note the influence of participating in professional training programs (Hwang \& Powell, 2009; MacIndoe \& Barman, 2012) as well as the influence of peers (Marshall \& Suarez, 2014; Mitchell, 2014). The recent growth of acceleration programs as 
cohort-based models that include both professional training as well as peer-to-peer learning (Pandey et al., 2017; Cohen \& Hochberg, 2014; Hallen et al., 2014) suggests that participation in these types of programs may be a reasonable proxy for the extent to which a social entrepreneur has been exposed to both professional training and the influence of peers. Social enterprise accelerators tend to offer roughly three months of intensified mentoring support, working with cohorts of 10-12 social enterprises that go through the program as a class, thus encouraging learning from trainers, mentors, and peers (Pandey et al., 2017; Cohen \& Hochberg, 2014; Casasnovas \& Bruno, 2013).

Therefore, we propose the following three hypotheses related to external factors:

Hla: Social enterprises that report receiving grant funding are more likely to have adopted social performance measurement practices.

H1b: Social enterprises that report seeking grant funding are more likely to have adopted social performance measurement practices.

H1c: Social enterprises that have previously participated in a cohort-based acceleration program are more likely to have adopted social performance measurement practices.

\section{Measuring to Improve (Rationalization in the Nonprofit Sector)}

In parallel to the literature on external legitimacy, some scholars argue that concept of social enterprise can be described as an extension of the steady trend toward rationalization and marketization of the nonprofit and social sectors identified in previous literature (Ebrahim et al., 2014; Eikenberry \& Kluver, 2004; Hwang \& Powell, 2009; Meyer et al., 2013). Dey \& Steyaert (2010) suggest that the "grand narrative" (p. 86) of social entrepreneurship offers an idealized and rational response to the chaos and complexity of social challenges, rooted in western orthodoxies of managerialism and performance assessment. In particular, the narrative of the 
social entrepreneurship field more broadly, and the form of social enterprise in particular, has been linked with rationalism as a broader means of solving problems, in order to remove uncertainties. These arguments are linked to the larger trends of rationalism and performativity (Dey \& Steyaert, 2010), managerialism (Suarez, 2010; Marshall \& Suarez, 2014) and marketization (Nickel \& Eikenberry, 2009; Eikenberry \& Kluver, 2004) of the social sector.

Therefore, it is somewhat surprising that we find relatively less research on the rationalized perspective and its influences on SPM in social enterprise, with a few notable exceptions. For example, Bagnoli \& Megali (2011) propose a performance measurement system for social enterprises that incorporates concerns of external legitimacy, financial performance, and an internally-driven managerial perspective on measuring social effectiveness. Using an illustrative case of an Italian work integration social enterprise, they observe the challenges associated with measuring social performance, and propose a logic-model based approach that incorporates inputs, outputs, outcomes, and impacts, as is commonly described in nonprofits (Ebrahim \& Rangan, 2010).

Similarly, other scholars have adapted or developed social performance tools specifically for social enterprise, including the Balanced Scorecard, originally developed by Kaplan and Norton (1996), and modified by Somers (2005) and Bull (2007). Somers incorporates the rationalized logic of measuring toward specific, measurable social objectives within the organization, while also incorporating the informational needs of external stakeholders, and tests this modified scorecard with twelve social enterprises. She finds that participants identified senior managers within the organization as the most important target group for the use of SPM tools, but also recognized the importance of building support from other key stakeholders both within and outside of the organization. She concludes that many performance measurement tools that are 
typically focused on external legitimacy may overlook the importance of internal uses of this information. However, Bull's (2007) test of the Balance tool (based on the Balanced Scorecard approach), with 30 UK based social enterprises shows that the majority of social enterprises were informally structured, and demonstrated low uptake of management systems and rationalized practices. Therefore, we suggest that despite the narrative of performativity and rationalism in social enterprise, the empirical evidence of these internal factors driving SPM is mixed.

In contrast to the relatively sparse (but growing) literature on this rationalized (i.e., measuring to improve) perspective of SPM in social enterprise, we find greater evidence of it in the nonprofit sector. While the concept of performance measurement more broadly may have been imported from the for-profit sector (Speckbacher, 2003), its application to measuring social impact or social performance has become institutionalized in the nonprofit sector over the past four decades, as a characteristic of rationalization and managerialism (Ebrahim et al., 2014; MacIndoe \& Barman, 2012; Thomson, 2011; Hwang \& Powell, 2009).

For example, Hwang \& Powell (2009) note the influence of venture philanthropy (Letts, Ryan \& Grossman, 1997) which draws heavily on metrics and measurement in shifting the nonprofit sector towards organizational rationalization. Hwang \& Powell (2009) define this process of rationalization as the "integration of formalized roles and rules" (p. 272), including the adoption of rationalized practices such as quantitative program evaluation and performance measurement. They consider the mechanism of normative isomorphism (DiMaggio \& Powell, 1983), and suggest that the transfer of rationalized practices occur not only due to external influences of funding agencies, but also through the backgrounds and experiences of professionals within the field, through the process of imprinting (Stinchcombe, 1965). 
We see emerging evidence that nonprofits view the practice of SPM not only as a form of compliance to external stakeholders, but as an integrated part of organizational strategy that also allows them a sense of independence (Arvidson \& Lyon, 2014). Arvidson \& Lyon's (2014) study of fourteen nonprofit organizations in the UK finds that over time, these practices become more integrated into the organizational profile, and reflect a change in culture as staff become more familiar with the processes and expectations of SPM. Eventually, these practices are part of the standard set of organizational activities, used by managers to manage performance and boost staff morale.

The importance of internal stakeholders is echoed by MacIndoe \& Barman (2012), in their quantitative analysis of 272 nonprofits and the measurement of outcomes. Critically, they find evidence that the board and staff are key internal stakeholders in influencing managers to adopt social outcome measurement practices. Roughly 60 percent of managers identified their boards as a central influence, and just under half (48.5\%) noted the staff as a key driving force, highlighting the internal embeddedness of these practices in the nonprofit field.

Finally, Thomson (2011) argues "Even in institutional environments where responsiveness to funders is the norm, funders' demands may have little impact on outcome measurement and use if institutional norms embraced outcome measurement before funders began demanding it." (p. 58). In his study of the performance measurement practices of 18 nonprofits in Detroit (USA), he finds that all the nonprofits in his study considered measuring a natural part of doing business, and had established procedures in place to measure social performance.

It is important to note that none of these perspectives preclude the importance of external influences and the effects of coercive isomorphic pressures (DiMaggio \& Powell, 1983) and resource dependency (Pfeffer \& Salancik, 1978) discussed previously. Instead, this 
complementary literature argues that external factors alone do not provide the entire picture of SPM in the social sector, and that the field has evolved over the past few decades. As such, these studies recognize that the initial impetus for SPM may have been due to concerns of external legitimacy, but over time these practices have been internalized in the nonprofit sector, through the mechanisms of normative isomorphic pressures (Thomson, 2011; MacIndoe \& Barman, 2012; DiMaggio \& Powell, 1983) and imprinting (Lee \& Battilana, 2010; Marquis \& Tilscik, 2013; Stinchcombe, 1965). Therefore, while we acknowledge that while external factors may still be important influences for SPM in the nonprofit sector, it seems likely that the internallydriven trend of rationalization has also contributed to the integration of these practices.

Battilana and Dorado (2010) note the strong influence of the background of staff and managers in organizational culture and practice in their comparison of two microfinance providers that were rooted in "social" and "commercial" logics. Similarly, Lee \& Battilana (2013) find that the backgrounds of the founders of social enterprises have a strong influence on the characteristics and practices of the organizations they create. Given the growing evidence of the embeddedness of SPM in the nonprofit field, we suggest that social enterprises that are more strongly rooted in the "social" institutional logic are more likely to retain these principles (Battilana \& Dorado, 2010; Lee \& Battilana, 2013). In some cases, these social roots may be reflected in the legal status of the organization (Battilana \& Dorado, 2010), while in others it may be related to the background of the founding team (Lee \& Battilana, 2013). We therefore propose the following hypotheses:

H2a: Social enterprises that are founded by entrepreneurs that have previously started a nonprofit organization are more likely to adopt social performance measurement practices. 
H2b: Social enterprises that are founded by entrepreneurs that have previously worked in a nonprofit organization are more likely to adopt social performance measurement practices.

H2c: Social enterprises that are registered as nonprofit organizations are more likely to adopt social performance measurement practices.

\section{DATA AND METHODS}

In this study, we use a new dataset developed by the Entrepreneurship Database Program at the Social Enterprise @ Goizueta Center at Emory University (Atlanta, USA), for our analysis. The center collected data from 22 social enterprise acceleration programs that implemented a survey as part of their application process, and aggregated observations from 2,374 self-identified social enterprises between January 2013 and December 2014. We note that the organizations that operate these acceleration programs specifically aim to work with nascent enterprises with a social or environmental mission, as illustrated by the language in their calls for applications:

“...provide entrepreneurs who are intentionally building businesses that solve social and environmental challenges in Latin America with the resources they need to grow."

...is an investment-readiness program supporting high-impact ventures with blended value propositions: social enterprises or social purpose businesses generating positive social or environmental impact and compelling financial returns."

“... for every program, we select a participating group - or "cohort" - of approximately 12 companies working to solve different problems in a specific sector (agriculture, education, energy, financial inclusion, or health).

Importantly, this dataset includes all the ventures that have applied to these programs, not only the ones that were accepted, somewhat reducing potential issues related to survivorship bias. In the absence of registries and reliable population estimates of the social enterprise sector, we believe this dataset provides a reasonable way to collect data on early-stage social enterprises. 
While the organizations that apply to these programs are self-identifying as social enterprises, the fact that they are applying to accelerators that specialize in supporting social enterprises (instead of commercial accelerators) suggests some level of commitment to a social objective.

Additionally, the social enterprises applying for these programs are required to explicitly describe their social mission in their applications, as well as answer multiple questions about their social objectives.

We drop 510 observations due to missing data in the independent and control variables, reducing the sample size to $1864 .{ }^{\mathrm{b}}$ The social enterprises in our sample are relatively young (median age of 1 year, mean of 2.7 years), and small (median size is 1 full-time employee in addition to the founding team, mean of 5.2 employees in addition to the founding team). The small size reflects the relatively early stage at which social entrepreneurs typically apply to acceleration programs, with few full-time employees beyond the founding team, so our study focuses on examining these questions as they relate to nascent social enterprises. The majority of ventures in the sample operate in high-income countries (42\%), followed by lower-middle income countries $(25 \%){ }^{\mathrm{c}}$

\section{Dependent Variable}

The application survey requires social enterprises to report on the use of two standardized measurement approaches (the IRIS measures developed by the Global Impact Investing Network and the B Impact Assessment developed by B Lab, described previously), as well as any other approaches that they use. For the purpose of this analysis, we do not distinguish between the different approaches reported, and use a single, dichotomous dependent variable called "reports adopting social performance measurement practices" that takes the value 1 if a social enterprise responds "Yes" to any of the following survey questions: 
- Does your venture regularly track itself against any of the IRIS impact measures?

- Has your organization ever taken a B Impact Assessment?

- Does your venture regularly track impacts using any other established measurement approaches?

As stated previously, our study does not aim to examine the quality, or extent of social performance measurement in social enterprise, only whether or not the venture reports making any effort to measure social performance. While this dataset does not allow for much more nuanced analysis on the type and quality of SPM, our research questions are primarily focused on understanding the factors that are associated with social enterprises choosing to measure their social performance in any way. Given the relatively limited empirical literature on this topic in social enterprise, we suggest this approach is an important first step to the more nuanced analyses of SPM, as conducted by Thomson (2011), MacIndoe \& Barman (2012), and others in the nonprofit sector. In this sample, $35 \%$ of the social enterprises report adopting some type of SPM practice (Table I).

\section{Independent Variables}

We use a series of dummy variables to operationalize the internal and external factors to be tested in this analysis. While the use of dichotomous variables can be challenging if potentially ambiguous attitudinal constructs are being used, it is less problematic for the directly observable factors that are uniformly understood and relatively unambiguous (Bergkvist and Rossiter, 2007).

Measuring to Prove (External Factors related to Legitimacy): As described previously, Nicholls (2008) describes the range of capital providers that typically provide social enterprises with 
funding, ranging from grants to commercial debt providers that expect market-rate financial returns. Nicholls suggests a strong link between issues of accountability and legitimacy and philanthropic or grant providers, a perspective that is supported by several scholars (notably Letts et al., 1997; Dees, 2008; Scarlata \& Alemany, 2010, among others). Since philanthropic providers are more likely to value social objectives, and therefore require their grantees to report on social performance, we create two dummy variables to capture the presence of grant-related external factors: The variable Reports receiving grant takes the value 1 if the social enterprise reports having received any grant funding in the past. Similarly, the variable Reports seeking grant takes the value 1 if the social enterprises reports seeking grant funding.

Finally, as we include a dummy variable that takes the value 1 if the social enterprise reports having previously participated in a cohort-based acceleration program. Prior participation in an acceleration program would expose them to professional training as well as an opportunity to learn from peers, both of which are shown to be strong external influences in the adoption of SPM practices in the nonprofit sector (Hwang \& Powell, 2009; Marshall \& Suarez, 2014; MacIndoe \& Barman, 2012).

Measure to Improve (Internal Factors related to Rationalization): As described previously, a number of researchers (notably Marshall and Suarez, 2014; Claeye and Jackson, 2012; Hwang and Powell, 2009) examine the growing adoption of "rationalizing" practices such as SPM in the nonprofit sector. As Battilana \& Dorado (2010) observe, social enterprises that are more strongly rooted in the nonprofit institutional logic are more likely to bring these practices over to the organizations that they create. Therefore, it is likely that social enterprises that are registered as nonprofits would be more likely to adopt social performance measurement practices, in keeping 
with the norms of the sector. Additionally, it is likely that social enterprise founders that have previously worked in, or founded nonprofit organizations would be more likely to adopt these practices in their new organizations. Therefore, we include a dummy variable Legal status nonprofit that takes the value 1 if the social enterprise is registered as a nonprofit organization. Additionally, we include two dummy variables to indicate the presence of prior founder experience in the nonprofit sector: The variable Prior nonprofit founding experience takes the value 1 if the social enterprise reports having at least one founder who has previously started a nonprofit organization. The variable Prior nonprofit work experience takes the value 1 if the social enterprise reports having at least one founder who has previously worked in the nonprofit sector.

Table I summarizes the descriptive statistics for the external and internal factors (independent variables) and the dependent variable in the model.

Insert Table I about here

\section{Control Variables}

In addition to the internal and external factors described previously, we control for a number of additional variables in the model. First, as several studies (notably Ormiston \& Seymour, 2011; Bull, 2007) find that social enterprises cite a lack of resources as a major barrier to the adoption of SPM, we suggest that it is likely that older, more mature ventures may be more capable of dedicating the resources towards measurement. Therefore, we include a continuous variable to 
control for the age of the venture. The median venture age in this sample is 1 year, and the mean venture age is 2.7 years.

Additionally, social impact investors that provide capital (in the form of debt or equity) to social enterprises, and expect both financial returns as well as social impact (Nicholls \& Pharaoh, 2008; Nicholls, 2010), may also influence these ventures to measure their social performance. Therefore, we also control for whether or not a venture reports receiving debt or equity funding, using two dummy variables that take the value 1 if the social enterprise reports receiving debt or equity funding, respectively.

We note that the social enterprises in our sample operate in over 60 countries. As several researchers (notably Newcomer et al., 2013 and Marshall and Suarez, 2014) note, SPM practices differ across developed and developing economies. Therefore, we introduce dummy variables for the income categories for the social enterprise' country of operations: low-income, lower-middle income, upper-middle income, and high income (reference category) to control for these differences.

Finally, it is likely that social enterprises that struggle to balance social and financial priorities may only focus their attention to SPM once they have positive revenues. As seen in past research, both social enterprises and nonprofits cite a lack of resources as an important barrier to the adoption of SPM (Ormiston \& Seymour, 2011; Ogain et al., 2012; Bull, 2007). Therefore, we include a dummy variable that takes the value 1 if the social enterprise reports having positive prior-year revenue.

Table II presents an overview of the key summary statistics for the control variables. 
Insert Table II about here

In addition to the control variables, since this sample draws from the application processes of 22 different acceleration programs, it is possible that ventures may systematically vary, depending on the specific social enterprise acceleration program that they are applying to (for example, some acceleration programs may be open to for-profit as well as nonprofit ventures, while some may only accept for-profits). To control for this variation, we include fixed effects for the accelerator program in the model.

We examine correlations between my independent and control variables in Table III, and note that all correlations coefficients are under 0.5 and the STATA computed Variance Inflation Factor for all variables is under 5 (well below the 10 limit prescribed by Acock, 2010). Therefore, the model does not appear to suffer from any issues of multicollinearity.

Insert Table III about here

Since our model uses a binary (dichotomous) dependent variable, we use a logistic regression model for our analysis. The logistic regression (or binomial logit) model, which is estimated using maximum likelihood, an iterative estimation method that produces normally distributed coefficient estimates, allows the use of typical hypothesis testing techniques and is considered more suitable for dummy dependent variable methods compared to the linear probability model (Studenmund, 2006). 
Model 1 introduces the control variables. In Model 2, we include the external and internal factors. Finally, in Model 3, we include fixed effects for the accelerator program from which the application data are drawn. Odds ratios, with robust standard errors in parentheses, are reported for all independent and control variables in Table IV. Additionally, we report a number of goodness-of-fit measures for each model, including the percentage of cases correctly classified, the Pseudo- $\mathrm{R}^{2}$, and the overall significance.

\section{Insert Table IV about here}

\section{RESULTS}

Somewhat surprisingly, our results show strong support for the hypotheses related to internal factors, and mixed support for the hypotheses related to external factors. Starting with the control variables in Model 1, we note that positive prior-year revenue is highly significant $(\mathrm{p}<0.01)$. Interestingly, social enterprises operating in low income countries and upper-middle income countries are significantly more likely to report adopting SPM practices compared to those in high income countries $(\mathrm{p}<0.01)$.

Once we introduce the external (measuring to prove) variables related to legitimacy in Model 2, we note that among the external factors, received grant funding is not statistically significant, while seeking grant funding is positively associated $(\mathrm{p}<0.01)$ with the adoption of SPM practices. Additionally, we find strong support for the influence of external training and peer-topeer interactions, with prior participation in an accelerator as highly significant $(\mathrm{p}<0.01)$. 
We also find strong support for the internal (measuring to improve) factors related to the influence strong roots in the social logic of the nonprofit sector. Specifically, social enterprises with at least one founder that has previously worked in a nonprofit are more likely to measure their social performance, as are social enterprises with founders that have previously started a nonprofit organization. Additionally, we find the odds of a social enterprise registered as a nonprofit measuring its social performance twice as high as those that are not registered as nonprofits $(\mathrm{p}<0.01)$.

Finally, in Model 3, we introduce fixed effects for the acceleration program from which the observations are drawn, to control for any systematic biases in the application processes. We focus our final analysis on Model 3, and do not observe support for hypothesis support for hypothesis H1a related to receiving grant funding. However, we do observe weak support for hypothesis H1b related to seeking grant funding. Specifically, the odds of a social enterprise that is seeking grant funding adopting SPM practices are 1.25 times that of a social enterprise that is not seeking a grant $(\mathrm{p}<0.10)$. Additionally, we find strong support for hypothesis H1c. Prior participation in an accelerator program is highly significant $(\mathrm{p}<0.01)$, and the odds of a social enterprise that has previously participated in an acceleration program adopting SPM practices are 1.6 times that of a social enterprise that has not previously been accelerated.

Prior nonprofit work experience and prior nonprofit founding experience continue to be highly significant in Model 3 ( $\mathrm{p}<0.01$ and $\mathrm{p}<0.05$ respectively), as well as nonprofit legal status $(\mathrm{p}<$ 0.01). The strong support for all three hypotheses related to internal factors $(\mathrm{H} 2 \mathrm{a}, \mathrm{H} 2 \mathrm{~b}$, and $\mathrm{H} 2 \mathrm{c})$ suggests that social enterprises that are more closely associated with the nonprofit sector (whether through legal status or the backgrounds of their founders) are more likely to adopt SPM 
practices, consistent with the norms of the nonprofit field. Finally, about two-thirds of the cases were correctly predicted by the 3 models, all of which are significant $(\mathrm{p}<0.01)$.

Overall, we find mixed support for hypotheses related to external factors (H1a is not supported, $\mathrm{H} 1 \mathrm{~b}$ is weakly supported, and H1c is strongly supported) across all the models, suggesting that while grant funders may not be as strongly associated with the adoption of SPM practices, the combination of professional training and peer interactions is strongly related. Interestingly, we find strong support for all three hypotheses $(\mathrm{H} 2 \mathrm{a}, \mathrm{H} 2 \mathrm{~b}$, and $\mathrm{H} 2 \mathrm{c})$ related to internal factors associated with the nonprofit sector, which highlights the possible strong influence of the nonprofit sector institutional logics. We summarize the results for all six hypotheses in Table V. Among our control variables, we find it particularly interesting to note that social enterprises in low-income and upper-middle income countries are significantly more likely to adopt SPM practices than those in high income countries. Not surprisingly, given the literature on resource constraints cited earlier, social enterprises with positive prior-year revenue are also significantly more likely to adopt SPM practices. In the following section, we discuss potential limitations of the study, along with a deeper discussion of the implications.

Insert Table $\mathrm{V}$ about here

\section{DISCUSSION}

Overall, our results show strong support for internal factors related to the influence of the nonprofit sector on SPM adoption in social enterprise. However, somewhat surprisingly, we find relatively low support for external factors associated with seeking or receiving grant funding, and 
strong support for factors related to professional training and peer interactions. This finding diverges considerably from qualitative research on these issues in social enterprise (notably Ormiston \& Seymour, 2011; Nicholls, 2009), as well as related qualitative and quantitative research in the nonprofit sector (notably Benjamin, 2010; Carman, 2011; MacIndoe \& Barman, 2012; Newcomer et al., 2013).

Interestingly, there is a strong relationship between nonprofit characteristics (not only legal status of the organization, but also the past experience of the founding team in the nonprofit sector) and the adoption of SPM practices by social enterprises. While we do not attribute any causal inference through this analysis, it appears that the past experience of the founding team in the nonprofit sector is a strong predictor of whether or not the social enterprise adopts SPM practices. This finding provides support to the view that the nonprofit sector has become increasingly rationalized and performance-driven in recent years, and that SPM is integrated into sector norms and expectations that may be transferred to the social enterprise sector.

As outlined previously, past research has found the background and motivations of founders influence the strategies, decisions and operating practices of organizations, and these features become institutionalized within the organization through the process of imprinting (Marquis \& Tilcsik, 2013). The strong relationship between founder backgrounds and the adoption of SPM practices suggests that imprinting (Marquis \& Tilcsik, 2013; Stinchcombe, 1965) may be a relevant theoretical framework to further examine this relationship. As noted by several scholars (Newcomer et al., 2013; Benjamin, 2010; Hwang \& Powell, 2009), the nonprofit sector has seen growing emphasis on SPM over the past decade. Therefore, it is understandable that social entrepreneurs that have previously founded or worked in nonprofits would carry these imprints to new organizations that they create. We suggest this finding represents an important direction 
for future research on the development and evolution of practices and norms in the social enterprise sector. While the use of imprinting has been used to examine characteristics of social enterprise (Lee \& Battilana, 2010), its use in studying SPM practices is an important contribution of this study.

However, in contrast to past research on the nonprofit sector, the limited support for some of the external factors related to funders is surprising, and may offer relevant insights for scholars and practitioners in the social enterprise and nonprofit sectors. In particular, we suggest that this finding may represent a progression of thought on the relative influence of external factors described by several social enterprise scholars (Ormiston \& Seymour, 2011; Nicholls, 2009). In contrast to prior qualitative research, our study suggests that social enterprises may not be as likely to be coerced to adopt SPM practices to appear legitimate to funders as previously thought. This finding is also highly relevant for practitioners, and offers some interesting insights on the continuing evolution of norms related to social performance measurement for the nonprofit and social enterprise sectors.

Finally, the finding related to prior participation in accelerator programs suggests some relationship between professional training and interacting with peers and the adoption of SPM practices, which is consistent with past research on the nonprofit sector (Marshall \& Suarez, 2014, Claeye \& Jackson, 2012; Hwang \& Powell, 2009). However, further research is needed to disentangle these two potential influences, to understand to what extent the relationship is based on the training or the peer interaction provided by the accelerator.

We acknowledge several potential limitations of this study. First, we note that some variables in the model may suffer from issues of construct validity. It is likely that the six variables used to capture different types of internal and external factors do not capture the range of potential 
influences. Additionally, since these data are taken from the applications to acceleration programs, it is possible that entrepreneurs may overstate or understate their responses to certain questions, due to social desirability bias.

We caution against drawing any causal inference through this study, which aims to be the first step in identifying potential antecedents of SPM practices in this field. We acknowledge that there are other factors that may influence social enterprises to adopt SPM practices that are not captured in this model, and the cross-sectional nature of the data make it difficult to establish causal inference. While we can determine that some of the variable constructs (prior work experience, prior founding experience, legal status) occurred before the adoption of SPM practices, others (such as receiving grant funding or participating in an accelerator program) could also have occurred during or after the adoption of SPM practices, which could raise concerns of reverse causality.

We suggest that further analysis using panel data and quasi-experimental methods (such as difference-in-difference) may address many of the internal validity issues that are present in this study. Finally, we note that the sample used for this analysis is based on data collected from selfidentified social enterprises applying to be part of incubation or acceleration programs, and is not representative of the broader population of social enterprises. Therefore, we caution against generalizing too broadly from any analysis in this study, and acknowledge the need to replicate the analysis with other samples, when possible.

Despite these limitations, this study makes an important first step at building quantitative evidence on SPM practices in social enterprise, and builds on a nascent but growing body of literature on the topic. Our study makes contributions to both the theory and practice of social performance measurement in social enterprise. Regarding theory, it extends the study of SPM to 
organizations with dual objectives, and provides a new theoretical perspective to study this important topic in social enterprise. The study also offers new insights on the influence of the nonprofit sector on social enterprise, while illustrating key differences between the two fields through its empirical findings. Finally, the findings related to the influence of accelerators on the adoption of SPM practices suggests new approaches for practitioners and funders that support social enterprises to develop more targeted training programs for the sector.

Additionally, our findings also pose some interesting questions for future research on this topic. First, if indeed, social enterprises with closer ties to the nonprofit sector are more likely to measure their social performance, are they truly adopting these practices to "improve" their social impact, or simply because of the norms that they have been influenced by in the past? Second, how do social enterprises use social and financial performance measurement? Are these measurement approaches integrated, or decoupled from each other? Finally, while this study has focused on external factors that would be characterized by relationships with organizations at the same or higher levels of accountability (to existing funders, potential funders, peers, etc.), it will be important to also examine this topic in the context of "downward" accountability to the beneficiaries of the social enterprise (Ebrahim et al., 2014). We believe that future quantitative and qualitative research can help to address these questions, and improve our understanding of the social performance of these organizations, and effective ways to measure it. 


\section{Notes}

a. Institutional logics have been described as taken for-granted social prescriptions that guide the behavior of actors (Friedland \& Alford, 1991; Suddaby \& Greenwood, 2005).

b. We do not observe any statistically significant differences in the descriptive statistics for key variables in the model between the original and reduced samples.

c. The World Bank classifies countries into 4 categories, based on their annual per capital income, as follows:

- Low Income: $\$ 1,035$ or less

- Lower-middle Income: $\$ 1,036$ to $\$ 4,085$

- Upper-middle Income: $\$ 4,086$ to $\$ 12,615$

- High Income: $\$ 12,616$ or more 


\section{References}

Acock, A. C. (2008). A gentle introduction to Stata. Stata press. Chicago

Arena, M., Azzone, G., \& Bengo, I. (2015). Performance measurement for social enterprises. VOLUNTAS: International Journal of Voluntary and Nonprofit Organizations, 26(2), 649-672.

Arvidson, M., Lyon, F., McKay, S., \& Moro, D. (2013). Valuing the social? The nature and controversies of measuring social return on investment (SROI). Voluntary Sector Review, 4(1), 3-18.

Arvidson, M., \& Lyon, F. (2014). Social impact measurement and non-profit organisations: Compliance, resistance, and promotion. VOLUNTAS: International Journal of Voluntary and Nonprofit Organizations, 25(4), 869-886.

Bagnoli, L., \& Megali, C. (2011). Measuring performance in social enterprises. Nonprofit and Voluntary Sector Quarterly, 40(1), 149-165.

Barman, E. (2015). Of Principle and Principal: Value Plurality in the Market of Impact Investing. Valuation Studies, 3(1), 9-44.

Battilana, J., \& Dorado, S. (2010). Building sustainable hybrid organizations: The case of commercial microfinance organizations. Academy of management Journal, 53(6), 14190.

Benjamin, L. M. (2008). Account space: How accountability requirements shape nonprofit practice. Nonprofit and Voluntary Sector Quarterly, 37(2), 201-223. 
Benjamin, L. M. (2010). Funders as principals. Nonprofit Management and Leadership, 20(4), 383-403.

Bergkvist, L., \& Rossiter, J. R. (2007). The predictive validity of multiple-item versus singleitem measures of the same constructs. Journal of marketing research, 44(2), 175-184.

Bull, M. (2007). "Balance": the development of a social enterprise business performance analysis tool. Social Enterprise Journal, 3(1), 49-66.

Carman, J. G. (2011). Understanding evaluation in nonprofit organizations. Public Performance \& Management Review, 34(3), 350; 350-377; 377.

Casasnovas, G., \& Bruno, A. V. (2013). Scaling social ventures: an exploratory study of social incubators and accelerators. Journal of Management for Global Sustainability, 1(2),

Claeyé, F., \& Jackson, T. (2012). The Iron Cage Re-Revisited: Institutional Isomorphism In Non-Profit Organisations In South Africa. Journal of International Development, 24(5), $602-622$

Cohen, S., \& Hochberg, Y. V. (2014). Accelerating startups: The seed accelerator phenomenon. Available at SSRN 2418000.

Dacin, P. A., Dacin, M. T., \& Matear, M. (2010). Social entrepreneurship: Why we don't need a new theory and how we move forward from here. The academy of management perspectives, 24(3), 37-57.

Dart, R. (2004). The legitimacy of social enterprise. Nonprofit management and leadership, 14(4), 411-424. 
Dees, J.D. (1998), “The Meaning of Social Entrepreneurship”, Centre for Advancement of Social Entrepreneurship (CASE), Fuqua School of Business, Duke University

Dees, J. G. (2008). Philanthropy and enterprise: Harnessing the power of business and social entrepreneurship for development. innovations, 3(3), 119-132.

Defourny, J., \& Nyssens, M. (2012). Conceptions of social enterprise in Europe: A comparative perspective with the United States. In Social Enterprises (pp. 71-90). Palgrave Macmillan

Dey, P., \& Steyaert, C. (2010). The politics of narrating social entrepreneurship. Journal of enterprising communities: people and places in the global economy, 4(1), 85-108.

DiMaggio, P. J., \& Powell, W. W. (1983). The iron cage revisited: Institutional isomorphism and collective rationality in organizational fields. American Sociological Review, 147-160.

Ebrahim, A., \& Rangan, V. K. (2014). What impact? California management review, 56(3), 118.

Ebrahim, A., Battilana, J., \& Mair, J. (2014). The governance of social enterprises: Mission drift and accountability challenges in hybrid organizations. Research in Organizational Behavior, 34, 81-100.

Ebrahim, A., \& Rangan, V. K. (2010). A contingency framework for measuring social performance. Harvard Business School. Social Enterprise Initiative.

Ebrahim, A. (2003). Making sense of accountability: Conceptual perspectives for northern and southern nonprofits. Nonprofit Management and Leadership, 14(2), 191-212.

Ebrahim, A. (2005). Accountability myopia: Losing sight of organizational learning. Nonprofit and voluntary sector quarterly, 34(1), 56-87. 
Ebrahim, A. (2003). Making sense of accountability: Conceptual perspectives for northern and southern nonprofits. Nonprofit Management and Leadership, 14(2), 191-212.

Ebrahim, A. (2002). Information struggles: The role of information in the reproduction of NGOfunder relationships. Nonprofit and Voluntary Sector Quarterly, 31(1), 84-114.

Edens, G. \& Lall, S. (2014). The State of Measurement Practice in the SGB Sector. The Aspen Institute.

Eikenberry, A. M., \& Kluver, J. D. (2004). The marketization of the nonprofit sector: civil society at risk? Public Administration Review, 64(2), 132-140.

Flockhart, A. (2005). Raising the profile of social enterprises: the use of social return on investment (SROI) and investment ready tools (IRT) to bridge the financial credibility gap. Social Enterprise Journal, 1(1), 29-42.

Galaskiewicz, J., \& Barringer, S. N. (2012). Social enterprises and social categories. Social enterprises: An organizational perspective: 47-80.

Hallen, B. L., Bingham, C. B., \& Cohen, S. (2014, January). Do Accelerators Accelerate? A Study of Venture Accelerators as a Path to Success? Academy of Management Proceedings (Vol. 2014, No. 1, p. 12955). Academy of Management.

Hehenberger, L., Harling, A. M., \& Scholten, P. (2013). A practical guide to measuring and managing impact. European Venture Philanthropy Association.

Hwang, H., \& Powell, W. W. (2009). The rationalization of charity: The influences of professionalism in the nonprofit sector. Administrative Science Quarterly, 54(2), 268-. 
Kaplan, R. S., \& Norton, D. P. (1996). The balanced scorecard: translating strategy into action. Harvard Business Press.

Kaplan, R.S. (2001) Strategic Performance Measurement and Management in Nonprofit Organizations, Nonprofit Management \& Leadership, 11(3), Spring 2001, pp. 353-370.

Kerlin, J. A. (2006). Social enterprise in the United States and Europe: Understanding and learning from the differences. Voluntas: International Journal of Voluntary and Nonprofit Organizations, 17(3), 246.

Kerlin, J. A. (2010). A comparative analysis of the global emergence of social enterprise. VOLUNTAS: international journal of voluntary and nonprofit organizations, 21(2), 162-.

Kerlin, J. (2009). Social enterprise: A global perspective. Lebanon: University Press of New England.

Koh, H., Karamchandani, A., \& Katz, R. (2012). From blueprint to scale: The case for philanthropy in impact investing. Monitor Group and Acumen Fund, April.

Lee, M., \& Battilana, J. (2013). How the zebra got its stripes: Imprinting of individuals and hybrid social ventures (Working Paper No. 14-005). Retrieved from Harvard Business School.

Lepoutre, J., Justo, R., Terjesen, S., \& Bosma, N. (2013). Designing a global standardized methodology for measuring social entrepreneurship activity: The Global Entrepreneurship Monitor social entrepreneurship study. Small Business Economics, 40(3), 693-714. 
Letts, C. W., Ryan, W., \& Grossman, A. (1997). Virtuous capital: What foundations can learn from venture capitalists. Harvard business review, 75, 36-50.

MacIndoe, H., \& Barman, E. (2013). How organizational stakeholders shape performance measurement in nonprofits: Exploring a multidimensional measure. Nonprofit and Voluntary Sector Quarterly, 42(4), 716-738.

Maier, F., Meyer, M., \& Steinbereithner, M. (2014). Nonprofit Organizations Becoming Business-Like A Systematic Review. Nonprofit and Voluntary Sector Quarterly, 0899764014561796.

Maier, F., Schober, C., Simsa, R., \& Millner, R. (2015). SROI as a Method for Evaluation Research: Understanding Merits and Limitations. VOLUNTAS: International Journal of Voluntary and Nonprofit Organizations, 26(5), 1805-1830.

Mair, J., \& Marti, I. (2006). Social entrepreneurship research: A source of explanation, prediction, and delight. Journal of world business, 41(1), 36-44.

Marquis, C., \& Tilcsik, A. (2013). Imprinting: Toward a multilevel theory. The Academy of Management Annals, 7(1), 195-245.

Marshall, J. H., \& Suárez, D. (2013). The flow of management practices: An analysis of NGO monitoring and evaluation dynamics. Nonprofit and Voluntary Sector Quarterly, 0899764013494117.

Meyer, M., Buber, R., \& Aghamanoukjan, A. (2013). In search of legitimacy: Managerialism and legitimation in civil society organizations. VOLUNTAS: International Journal of Voluntary and Nonprofit Organizations, 24(1), 167-193. 
Mitchell, G. E. (2014). Why will we ever learn? Measurement and evaluation in international development NGOs. Public Performance \& Management Review, 37(4), 605-631.

Miller, T. L., Wesley, I. I., \& Curtis, L. (2010). Assessing mission and resources for social change: An organizational identity perspective on social venture capitalists' decision criteria. Entrepreneurship Theory and Practice, 34(4), 705-733.

Milligan, K., \& Schöning, M. (2011). Taking a realistic approach to impact investing: Observations from the World Economic Forum's Global Agenda Council on Social Innovation. innovations, 6(3), 155-166.

Moore, M. L., Westley, F. R., \& Brodhead, T. (2012). Social finance intermediaries and social innovation. Journal of Social Entrepreneurship, 3(2), 184-205.

Newcomer, K., Baradei, L. E., \& Garcia, S. (2013). Expectations and Capacity of Performance Measurement in NGOs in the Development Context. Public Administration and Development, 33(1), 62-79.

Nicholls, A. (2010). The Legitimacy of Social Entrepreneurship: Reflexive Isomorphism in a Pre-Paradigmatic Field. Entrepreneurship Theory and Practice, 44(0), 611-634.

Nicholls, A. (2009). "We do good things, don't we?': "Blended Value Accounting” in social entrepreneurship. Accounting, Organizations and Society, 34(6-7), 755-769.

Nicholls, A. (ed), (2010) Social Entrepreneurship: New Models of Sustainable Social Change, Oxford University Press, pp. 99-118

Nicholls, A., \& Cho, A. H. (2006). Social entrepreneurship: The structuration of a field. Social entrepreneurship: New models of sustainable social change, 99-118. Palgrave MacMillan. 
Nicholls, A., \& Pharoah, C. (2008). The landscape of social investment: A holistic topology of opportunities and challenges.

Nickel, P. M., \& Eikenberry, A. M. (2009). A critique of the discourse of marketized philanthropy. American Behavioral Scientist, 52(7), 974-989.

Ógáin, E., Lumley, T., \& Pritchard, D. (2012). Making an impact: Impact measurement among charities and social enterprises in the UK. London: New Philanthropy Capital.

Ormiston, J. \& Seymour, R. (2011): Understanding Value Creation in Social Entrepreneurship: The Importance of Aligning Mission, Strategy and Impact Measurement, Journal of Social Entrepreneurship, 2:2, 125-150

Pandey, S., Lall, S., Pandey, S. K., \& Ahlawat, S. (2017). The Appeal of Social Accelerators: What do Social Entrepreneurs Value?. Journal of Social Entrepreneurship, 1-22.

Pfeffer, J., \& Salancik, G. R. (1978). The external control of organizations: A resource dependence approach. NY: Harper and Row Publishers.

Powell, W. W., \& Friedkin, R. (1986). Politics and programs: Organizational factors in public television decision making. Nonprofit enterprise in the arts, 245-269.

Ridley-Duff, R., \& Bull, M. (2015). Understanding social enterprise: Theory and practice. Sage.

Scarlata, M., Gil, L. A., \& Zacharakis, A. (2012). Philanthropic venture capital: Venture capital for social entrepreneurs?. Foundations and Trends in Entrepreneurship, 8(4), 279-342.

Scarlata, M., \& Alemany, L. (2010). Deal structuring in philanthropic venture capital investments: Financing instrument, valuation and covenants. Journal of Business Ethics, $95(2), 121-145$. 
Schiff, H., Bass, R., \& Cohen, A. (2016). The Business Value of Impact Measurement. The Global Impact Investing Network.

Somers, A. B. (2005). Shaping the balanced scorecard for use in UK social enterprises. Social Enterprise Journal, 1(1), 43-56.

Speckbacher, G. (2003). The economics of performance management in nonprofit organizations. Nonprofit management and leadership, 13(3), 267-281.

Spiess-Knafl, W., \& Aschari-Lincoln, J. (2015). Understanding mechanisms in the social investment market: what are venture philanthropy funds financing and how?. Journal of Sustainable Finance \& Investment, 5(3), 103-120.

Stinchcombe, A. L. (1965). Social structure and organizations. Handbook of organizations, 142.

Studenmund, A. (2006). Econometrics: A Practical Guide. Addison Wesley

Suarez, D. F. (2010). Street credentials and management backgrounds: Careers of nonprofit executives in an evolving sector. Nonprofit and Voluntary Sector Quarterly, 39(4), 696-7

Teasdale, S. (2012). What's in a name? Making sense of social enterprise discourses. Public policy and administration, 27(2), 99-119.

Terjesen, S., Lepoutre, J., Justo, R., \& Bosma, N. (2011). Global Entrepreneurship Monitor: 2009 Report on Social Entrepreneurship.

Thomson, D. E. (2011). The role of funders in driving nonprofit performance measurement and use in strategic management. Public Performance \& Management Review, 35(1), 54-78.

Useem, M. (1987). Corporate philanthropy. The nonprofit sector: A research handbook, 340-359. 
Young, D. R. (2012). The state of theory and research on social enterprises. Social Enterprise:

An Organizational Perspective, Basingstoke: Palgrave Macmillan, 19-43.

\section{TABLES AND FIGURES}

Table I: Dependent and Independent Variables

\begin{tabular}{ll}
\hline Dummy Dependent Variable & Proportion (\% Yes) \\
\hline Reports adopting any SPM Practices & $35 \%$ \\
\hline Dummy Independent Variables & Proportion (\% Yes) \\
\hline External Factors (Measuring to Prove) & \\
Reports receiving grant & $50 \%$ \\
Reports seeking grant & $49 \%$ \\
Previously participated in accelerator & $27 \%$ \\
& \\
Internal Factors (Measuring to Improve) & \\
Prior nonprofit founding experience on team & $37 \%$ \\
Prior nonprofit work experience on team & $29 \%$ \\
Legal Status Nonprofit & $12 \%$
\end{tabular}

Table II: Control Variables

\begin{tabular}{lc}
\hline Continuous Variables & Mean (Median) \\
\hline Venture Age & 1 year (2.7 years) \\
\hline Dummy Variables & Proportion of Ventures (\%) \\
\hline Report Receiving Debt & $19 \%$ \\
Report Receiving Equity & $23 \%$ \\
Report Positive Prior-year Revenue & $44 \%$ \\
Low Income Country & $20 \%$ \\
Lower-middle Income Country & $24.5 \%$ \\
Upper-middle Income Country & $13.4 \%$
\end{tabular}


Table III: Correlation Matrix

\begin{tabular}{|c|c|c|c|c|c|c|c|c|c|c|c|c|c|}
\hline & $(1)$ & $(2)$ & $(3)$ & $(4)$ & $(5)$ & $(6)$ & $(7)$ & $(8)$ & $(9)$ & $(10)$ & $(11)$ & $(12)$ & $(13)$ \\
\hline 1. Received Equity & & & & & & & & & & & & & \\
\hline 2. Received Debt & .17 & & & & & & & & & & & & \\
\hline 3. Venture Age & .06 & .18 & & & & & & & & & & & \\
\hline 4. Positive Revenue & .09 & .22 & .29 & & & & & & & & & & \\
\hline 5. Low Inc. Country & -.01 & .06 & .03 & .11 & & & & & & & & & \\
\hline 6. Lower-middle Inc. Country & -.03 & .05 & .08 & .05 & -.28 & & & & & & & & \\
\hline 7. Upper-middle Inc. Country & -.01 & .02 & .02 & .03 & -.2 & -.22 & & & & & & & \\
\hline 8. Received grant funding & .03 & .11 & .04 & .1 & .07 & -.07 & .02 & & & & & & \\
\hline 9. Seeking grant funding & -.06 & .07 & -.01 & .04 & .2 & -.06 & .01 & .43 & & & & & \\
\hline 10. Prior NP Work Exp. & -.04 & -.06 & -.02 & .03 & .14 & -.04 & -.08 & .13 & .18 & & & & \\
\hline 11. Prior NP Founding Exp. & .04 & .02 & .01 & .06 & .12 & -.05 & .00 & .1 & .14 & .28 & & & \\
\hline 12. Legal Status NP & -.1 & -.05 & .08 & .04 & .08 & -.05 & -.02 & .14 & .21 & .20 & .03 & & \\
\hline 13. Previously accelerated & .09 & .02 & -.02 & .03 & .09 & -.04 & -.01 & .07 & .04 & .02 & .04 & .00 & \\
\hline
\end{tabular}


Table IV: Odds Ratios for Social Enterprise Adopts SPM Practices (Logistic Regression)

\begin{tabular}{|c|c|c|c|}
\hline & $\begin{array}{c}\text { (1) } \\
\text { Control } \\
\text { Variables } \\
\end{array}$ & $\begin{array}{c}(2) \\
\text { Internal \& External } \\
\text { Factors } \\
\end{array}$ & $\begin{array}{c}\text { (3) } \\
\text { Program Fixed Effects }\end{array}$ \\
\hline Received Equity & $\begin{array}{c}1.16 \\
(0.14)\end{array}$ & $\begin{array}{c}1.22 \\
(0.15)\end{array}$ & $\begin{array}{l}1.24 * \\
(0.16)\end{array}$ \\
\hline Received Debt & $\begin{array}{c}1.04 \\
(0.14)\end{array}$ & $\begin{array}{c}1.06 \\
(0.14)\end{array}$ & $\begin{array}{c}1.06 \\
(0.15)\end{array}$ \\
\hline Venture Age (at time of application) & $\begin{array}{c}1.02 \\
(0.01)\end{array}$ & $\begin{array}{c}1.02 \\
(0.01)\end{array}$ & $\begin{array}{c}1.02 \\
(0.01)\end{array}$ \\
\hline Positive Prior Year Revenue & $\begin{array}{l}1.44 * * * \\
(0.15)\end{array}$ & $\begin{array}{c}1.38^{* * *} \\
(0.15)\end{array}$ & $\begin{array}{l}1.29 * * \\
(0.15)\end{array}$ \\
\hline Low Income Country & $\begin{array}{c}1.93 * * * \\
(.26)\end{array}$ & $\begin{array}{c}1.58 * * * \\
(.22)\end{array}$ & $\begin{array}{c}1.59 * * \\
(.35)\end{array}$ \\
\hline Lower-middle Income Country & $\begin{array}{l}.97 \\
(.13)\end{array}$ & $\begin{array}{l}1.02 \\
(.14)\end{array}$ & $\begin{array}{l}1.23 \\
(.24)\end{array}$ \\
\hline Upper-middle Income Country & $\begin{array}{c}1.65 * * * \\
(.25)\end{array}$ & $\begin{array}{c}1.71 * * * \\
(.27)\end{array}$ & $\begin{array}{c}1.71 * * \\
(36)\end{array}$ \\
\hline Received Grant (External Factors) & & $\begin{array}{c}1.17 \\
(0.13)\end{array}$ & $\begin{array}{c}1.21 \\
(0.15)\end{array}$ \\
\hline Seeking Grant (External Factors) & & $\begin{array}{c}1.3^{*} \\
(0.15)\end{array}$ & $\begin{array}{l}1.25^{*} \\
(0.15)\end{array}$ \\
\hline $\begin{array}{l}\text { Prior Participation in Accelerator } \\
\text { (External Factors) }\end{array}$ & & $\begin{array}{l}1.64 * * * \\
(0.18)\end{array}$ & $\begin{array}{c}1.63 * * * \\
(0.2)\end{array}$ \\
\hline $\begin{array}{l}\text { Prior Nonprofit Work Experience } \\
\text { (Internal Factors) }\end{array}$ & & $\begin{array}{c}1.35^{* * * *} \\
(0.15)\end{array}$ & $\begin{array}{c}1.38 * * * \\
(0.16)\end{array}$ \\
\hline $\begin{array}{l}\text { Prior Nonprofit Founding Experience } \\
\text { (Internal Factors) }\end{array}$ & & $\begin{array}{l}1.28 * * \\
(0.13)\end{array}$ & $\begin{array}{l}1.31 * * \\
(0.15)\end{array}$ \\
\hline $\begin{array}{l}\text { Nonprofit Legal Status (Internal } \\
\text { Factors) }\end{array}$ & & $\begin{array}{l}2.11 * * * \\
(0.33)\end{array}$ & $\begin{array}{l}2.01 * * * \\
(0.18)\end{array}$ \\
\hline $\begin{array}{l}\text { Accelerator Program Fixed Effects } \\
N \\
\text { Hit Rate (\% Correctly Classified) } \\
\text { Pseudo } R^{2}(\text { Cragg \& Uhler) } \\
\text { Overall Significance }\end{array}$ & $\begin{array}{l}\text { No } \\
1864 \\
65.67 \% \\
.05 \\
* * *\end{array}$ & $\begin{array}{c}\text { No } \\
1864 \\
67.70 \% \\
.11 \\
* * *\end{array}$ & $\begin{array}{c}\text { Yes } \\
1864 \\
68.24 \% \\
.15 \\
* * *\end{array}$ \\
\hline
\end{tabular}


* Significant at the $\mathrm{p}<0.10$ level

$* *$ Significant at the $\mathrm{p}<0.05$ level

$* * *$ Significant at the $\mathrm{p}<0.01$ level

Robust standard errors in parentheses

\section{Table V: Summary of Results}

\begin{tabular}{|l|l|}
\hline Hypothesis & Finding \\
\hline External Factors & Not supported \\
\hline $\begin{array}{l}\text { H1a: Social enterprises that report receiving grant funding are more likely to } \\
\text { have adopted SPM practices. }\end{array}$ & $\begin{array}{l}\text { Weakly supported } \\
\text { ( }<0.10)\end{array}$ \\
\hline $\begin{array}{l}\text { H1b: Social enterprises that report seeking grant funding are more likely to } \\
\text { have adopted SPM practices. }\end{array}$ & $\begin{array}{l}\text { Strongly supported } \\
\text { (p<0.01) }\end{array}$ \\
\hline $\begin{array}{l}\text { H1c: Social enterprises that have previously participated in a cohort-based } \\
\text { acceleration program are more likely to have adopted SPM practices. }\end{array}$ & Supported $(\mathrm{p}<0.05)$ \\
\hline Internal Factors & $\begin{array}{l}\text { H2a: Social enterprises that are founded by entrepreneurs that have previously } \\
\text { started a nonprofit organization are more likely to adopt SPM practices. }\end{array}$ \\
\hline $\begin{array}{l}\text { H2b: Social enterprises that are founded by entrepreneurs that have previously } \\
\text { worked in a nonprofit organization are more likely to adopt SPM practices. }\end{array}$ & $\begin{array}{l}\text { Strongly supported } \\
\text { ( }<<0.01)\end{array}$ \\
\hline $\begin{array}{l}\text { H2c: Social enterprises that are registered as nonprofit organizations are more } \\
\text { likely to adopt SPM practices. }\end{array}$ & $\begin{array}{l}\text { Strongly supported } \\
(\mathrm{p}<0.01)\end{array}$ \\
\hline
\end{tabular}


Figure 1: Theoretical Framework \& Hypotheses

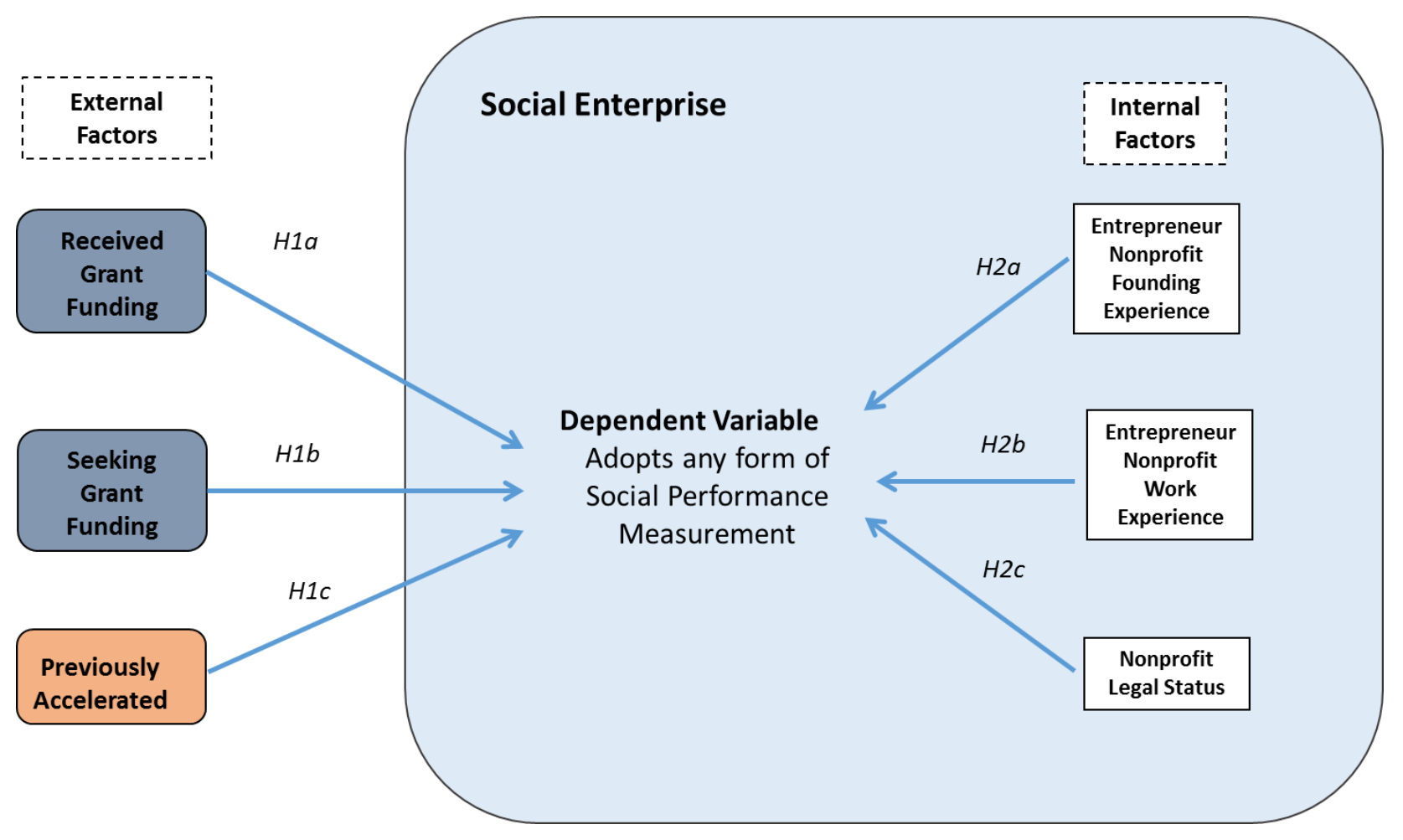

